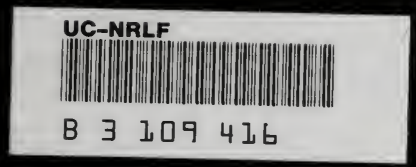




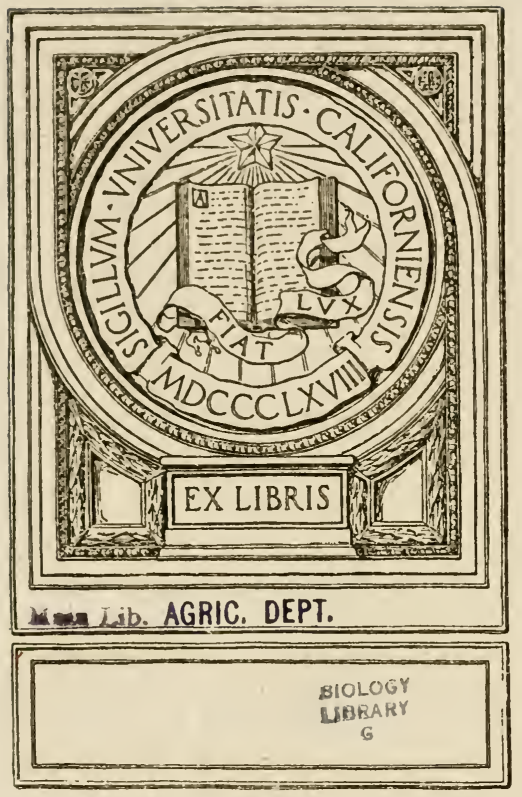





Digitized by the Internet Archive in 2008 with funding from Microsoft Corporation 


\section{SOME RESULTS OF CASTRATION IN DUCKS.}

H. D. GOODALE.

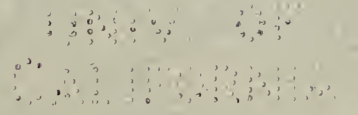

[Reprinted from Biological Bulletin, Vol. XX., No. I, December, 1910.] 

[Reprinted from Biological Bulletin, Vol. XX., No. I, December, I9io.

\section{SOME RESULTS OF CASTRATION IN DUCKS. ${ }^{1}$}

H. D. GoOdale.

Introduction.-The present paper is largely in the nature of a first report and will be followed by others as the experiments warrant. In addition to a brief review of some other studies on castration, I have considered, also very briefly, some problems relating to sexual dimorphism, sex-limited inheritance and the determination of sex.

It is a matter of rather common knowledge that females of birds and mammals, which have become sterile from any cause, may assume the plumage and other secondary sexual characters of the male. On the other hand, the male when castrated, often does not develop his usual trappings. This has often been interpreted as a development of the female characters. It has, however, been pointed out that castration of the young male causes rather a retention of his own youthful characters.

Castration, besides its effect on the secondary sexual characters, may lead to certain specific changes in the organism, not correlated with secondary sexual characters. Thus the capon grows larger than the cock and is more sluggish. Tandler and Grosz found in man, among other things, that there was a tendency for fat to develop in certain regions, and either a failure, or poor development of body, axial, and pubic hairs.

The present paper deals almost wholly with the effect of castration on the secondary sexual characters.

The breed known as Rouens was selected for this work, largely because they are strongly sexually dimorphic in plumage. ${ }^{2}$

The Rouens are probably derived from the mallard, Anas boschas. Coues says, "nearly everywhere domesticated, being the well known original of the barnyard duck." In some respects the Rouens differ from the mallard. The latter are much smaller.

${ }^{1}$ For the suggestion of studying the effects of castration in ducks, I am indebted to Professor T. H. Morgan.

${ }^{2}$ The individuals used in these experiments were reared from eggs secured from the Whitc Birch Poultry Farm, Bridgewater, Mass. 
The tail of the male has some white, while in summer plumage he resembles the female Rouen. (For description of latter see below.) The female mallard, though of the same general color, is of much lighter tone throughout than the Rouen female, which might easily pass as a melanistic variety of the former. For practical purposes we are dealing with a wild species.

In addition to a general description, I have given a somewhat detailed description of the feathers of the various sections of the birds. There is, however, so much variation in the patterns of the feathers of the female and the male in his summer plumage, that these descriptions and figures illustrate only a few types. This variation exists, not only between different birds, but even in a single section of one individual. Though two feathers are rarely exactly alike, the majority of feathers in a single section have a general resemblance. On the other hand the feathers of each section of the male's breeding plumage are very constant in type.

\section{General Descriptions.}

Male in Breeding Plumage (Fig. I).-Bill: greenish yellow. Head and upper part of neck: rich metallic green. Then comes a narrow white ring often not quite complete dorsally. Ventral side of remainder of neck and a large part of breast: rich claret. Remainder of ventral surface: iron gray, becoming lighter toward the anus. Posterior to the last it becomes darker. Back: very dark gray in neck region, becoming still darker in the middle and greenish black on the rump. The two median tail feathers are strongly curved antero-dorsally. They have the same color as the rump. The next two are often curved, but may be duller in color. These four form the so-called sex feathers. The rest of the tail and the upper surface of wing is brownish black. The latter has a speculum of iridescent purple. Under surface of wing: white. The drake's voice is a soft qua, either rapidly repeated, with a slight pause after every other note, or else a somewhat louder, single note, much prolonged. In some varieties the voice and sex feathers are the only conspicuous secondary sexual characters.

Female (Fig. 2).- Throughout a mixture of buff and dark brown. Bill: brownish black, usually mottled with yellow. Occu- 


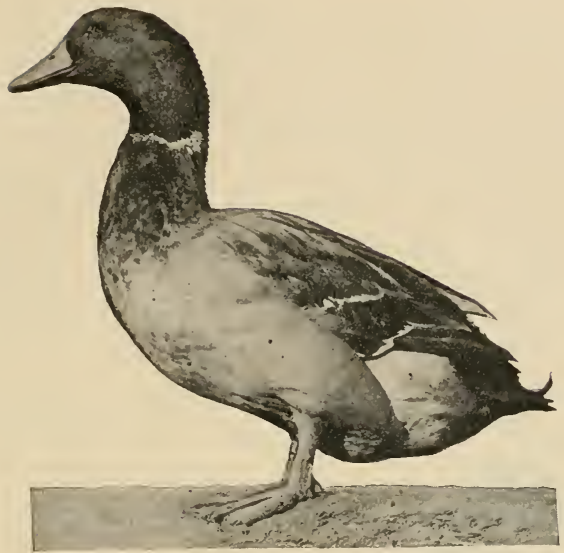

FIG. I. Male in breeding plumage.

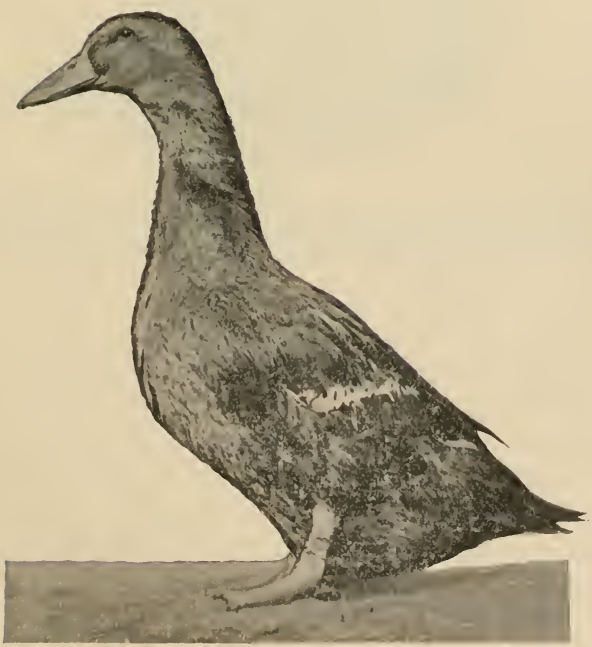

Fig. 2. Normal female. 
pying the dorsal side of the head and upper neck is a broad dark stripe, tinged with green and inconspicuously striped with buff. The sides of the head are buff with small dark flecks. Passing across the side of the head from the nostril through the eye to the dorsal surface and from the angle of the jaw to the eye, are two dark bands. Sides of upper neck: mixed buff and dull black. Throat: buff. Dorsal surface of body often much darker than ventral, and usually less conspicuously striped. Speculum and under surface of wing as in the male. Sex feathers absent. Voice a loud quack. At times it is modified into a softer, rapidly repeated quac.

Summer Plumage.-At the close of the breeding season,

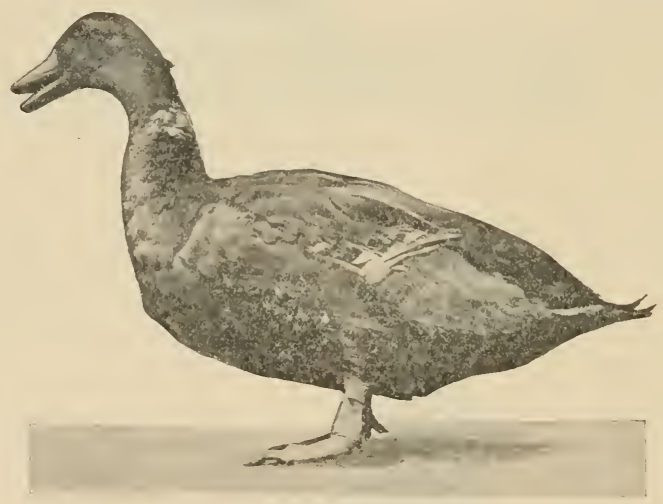

FIG. 3. Male in summer plumage.

which comes early in July, both sexes molt. The new coat of the male, when complete, is different from the old (Fig. 3). The molt, however, takes place piece-meal, certain sections being nearly completed before others begin. Consequently there is only a very brief period at the end of the summer when the new coat exists as a whole. Then the transition begins again to the usual coat which is completed early in October. In the modified coat the male is said to be in "summer plumage," or in a "state of eclipse."

Head: similar to that of female. Breast: mottled dull black 
and reddish buff. Keel: dull slate with buffish streaks. Remainder not conspicuously modified. Sex feathers absent.

The female, so far as I have observed, undergoes no radical change in coat color, though in one case, at least, the patterns of the feathers were considerably different in August from those of October. Compare Fig. $4, E$ with $F$; Fig. 6, $D$ with $F$.

As a result of the molt in early summer, both sexes of the adult and the young are quite similar for a time. Its meaning is uncertain. Newton ascribes the assumption of the summer plumage by the drake to the loss of the power of flight temporarily, since the remiges all fall out together. But in other cases where a similar double molt occurs, the male retains the modified plumage for several months; nor does he become incapable of flight. As will be shown later, the presence of the active testis is necessary for the drake to assume this plumage. Conditions in the mallard, as far as I can find out, appear to be somewhat different from the Rouen. The summer plumage seems to persist longer. The one male in the American Museum in a transition stage, had a brown edging to the feathers of regions, which, in the male Rouen, have no such edging.

Young.-When first hatched the young are brownish black with a few yellowish stripes or spots. While they are acquiring their first coat of feathers both sexes resemble the female in general appearance. This summer, however, I found certain characters of the plumage by which the sexes could be distinguished at a very early age (Fig. 8, D, E, from birds about 7 weeks old). The young "peep" for several weeks after hatching. The voice of the young female is modified into that of the adult a few weeks before that of the young drake. The latter is about four months old when he takes on the adult plumage. At this time the testes are still very small.

Description of Feathers. ${ }^{1}$-Male in breeding plumage.-Head and upper neck: distal half, metallic green; proximal half, dull black with narrow white base; on the ventral side of head, this base may be more extensive. Neck ring: entirely white. The feathers of regions immediately adjoining the neck ring may be many kinds of mixtures of white, red and black. Ventral surface.

'The words distal and proximal refer to the feathers. 
-Lower throat: distal half, deep claret; proximal half slate, sometimes stippled or spotted with buff. Breast: distal half claret; remainder slate, becoming white at base, usually stippled with buff (Fig. $4 . A$ ); sometimes numerous transverse vermiculations are present (Fig. $4, B$ ); less frequently, still other slight modifications may occur. Keel (Fig. $5, A, B$ ) and laterals : ${ }^{1}$ light gray becoming darker proximally; distal half traversed by numerous transverse slate colored vermiculations; ${ }^{2}$ near the breast region the tip of the feather may be shaded with faint claret (Fig. 5, B). Posterior to vent: (Fig. $8, I$ ) similar to preceding, but the slate vermiculations are much broader and often become confluent, forming patches. Sides posterior to folded wing: (Fig. $8, J)$ similar to keel but much lighter; vermiculations often broken; proximally: slate at base, but more distally of ten changes abruptly to white. Under tail converts: black becoming lighter toward the base; exposed surface with metallic sheen. Dorsal surface.-Lower neck near body: slate, becoming somewhat lighter toward the base; light gray vermiculations distally (Fig. 6, $A$ ). Passing back along the back the gray vermiculations tend to disappear except at the edge of the feathers. The slate also gradually gives place to black which as it nears the rump becomes metallic blue or green on its exposed surface. Rump (Fig. $7, A$ ), upper tail coverts and sex feathers: black with metallic green or blue on the exposed surface; vermiculations rarely occur. Main tail, primaries and primary coverts: dull brownish black. Secondaries: a narrow white band across the tip; remainder, outer surface, dorsal side of vane: dull brownish black; ventral side of vane: next to white tip a narrow velvety black band; the rest, except for a narrow dull band near the base is brilliant changeable purple, blue or green; inner surface, dull brownish black. The innermost secondaries: slate, often with velvety black. Secondary coverts: velvety black band across the tip, then a narrow white band, remainder brownish black. Remainder of upper surface of wing: brownish black. The feathers at the anterior edge have gray vermiculations which disappear posteriorly. Scapulars: various modifications of the

\footnotetext{
IOn the sidrs of the body just beneath the edge of the folded wing is an elongated patch of very large feathers, which I have thus designated.

${ }^{21}$ lave arbitrarily called the narrowest bands vermiculations.
} 
uniform slate and gray vermiculated types. There is also a peculiar tuft of small feathers just anterior to the junction of the wing and body. Each feather (Fig. $8, A$ ) has a narrow band of slate and light gray vermiculations across the tip, then a curved band of light claret, the remainder being a mixture of slate and gray.

Male in Summer Plumage.-Top of head: almost identical with normal type, but much less brilliant. Light line above eye: distal half mostly buff with small irregular blotches of black; base, dull black; sometimes the entire feather is nearly black. Beneath the eye: dull black; distal half with buff edges. Throat: reddish buff with irregular dull black marks; basal half slate. Upper breast: (Fig. 4, C) bands of reddish buff or claret and dull black; though irregular they are more or less transverse; basal half: slate. Regular patterns may occur (Fig. 4, D). Lower breast: buff in place of reddish buff; otherwise as preceding; sometimes feathers like those of one of the female types are found (Fig. 5, D). Anterior keel: (Fig. 5, C) mostly slate; margin of varying width vermiculated with gray; tip usually of rufus shade. Posterior keel: dull slate, vermiculated margins reduced or absent. Posterior to vent: dull black with vermiculated margins. Under tail coverts: dull black with narrow buff margin on exposed part, sometimes vermiculated. Sides of body posterior to wing: (Fig. 8, $H$ ) slate with narrow gray vermiculations. Dorsal surface of body: modifications often slight throughout; the feathers at union of neck with body (Fig. 6, C) lose most of their vermiculations and may have buff edges. Scapulars: dull slate. Laterals somewhat modified, often with a distinct tendency for the formation of transverse reddish buff and black bands across the tip, similar to those of the breast; vermiculations reduced or absent.

Female.-Top of head: distal half, dull greenish black with buff margins; basal half slate. Line above eye: reddish buff with median dark stripe; basal half slate. Throat: reddish buff with gray base. Upper neck at junction with next section : buff with irregular longitudinal dark stripes; base slate. Breast: buff, sometimes reddish, with dark patches, arranged in numerous patterns (Fig. 4, $E-H$ ). Keel: (Fig. 5, $E, F$ ) similar to preceding 
but usually duller and if anything less regular in pattern. Near the anus the feathers are apt to show a more regular pattern similar to Fig. 4, E. Dorsal surface: anteriorly (Fig. 6, D, E), rather brighter colors than elsewhere and of ten a distinctly more regular pattern. Fig. $6, D$, closely approximates the fancier's ideal. Posteriorly the pattern becomes variable again and colors duller (Fig. $7, C, E$ ). In some females the entire dorsal surface is almost black, as the buff markings become faint (Fig. $7, E$ ). Main tail: brownish black, with narrow buff margins. Junction of wing with body: (Fig. 8, C) light rufous with irregular black spots. Scapulars: various modifications of "ideal" type. Upper surface of wing not including remiges: dull black with buff margins. Remainder of wing like males except that inner secondaries have some tendency toward developing white bands.

Young.- Unfortunately I have only a few notes on the feathers of the young. In one young female, the breast (Fig. 8, E) and keel feathers were dull brownish black with a buff margin, which is very narrow at the apex. The rump feathers were black with a narrow subapical buff band bounded by a margin of black.

In two young males the breast feathers were dull black, the distal half margined with buff and having two narrow transverse subapical buff bands (Fig. 8, D). The keel feathers were like those of the young female. The rump feathers were black like those of the adult male.

The general appearance of the young female, even before she gets a full coat of feathers, is like that of the adult. The young male, too, resembles the female, until one learns the characters which distinguish him from his sisters.

The Relation between the Summer Plumage of the Male and the Female's Plumage.

These descriptions show that the male in summer plumage merely mimics the female. He does not even become entirely like her. In certain sections, as pointed out, there are no modifications toward the female type. In others, $i$. $e$, the head, breast and keel region, the feathers of the male become quite like those of the female. Individual feathers may be indistinguishable from female feathers. But the male in addition has 
types of feathers which the female lacks. Thus, the feathers of the top of the head have no buff edges. Those of the posterior keel region may have gray vermiculations on the margins. Those of the throat and upper neck regions, however, appear to be nearly identical with female feathers of the same sections. The breast feathers present some complications. Certain types of these are common to both sexes, but the male has certain forms not possessed by the female. The differences, though elusive, may perhaps be stated as follows: The apical part of the male's breast feather is claret; that of the female is buff. There is a tendency in the male for the red or buff bands to increase from two to three and to become transverse. In the female the tendency is for the bands to become reduced in number and to become longitudinal. Only a statistical study could determine just the exact relations between the two sexes.

This discussion, I think, makes it clear that the modifications in the plumage of the male are, on the whole, of a type peculiar to his sex. It can hardly be maintained that this is an example of the assumption by the male of the female's plumage, especially as I shall show later, the presence of the testis is necessary for its appearance. The power to change his plumage is, indeed, a sort of physiological secondary sexual character.

\section{EXPERINENTS.}

Thus far I have castrated 7 males and 5 females. ${ }^{1}$ Three males and two females lived for considerable periods. No. $4700^{7}$ and 4 ㅇ were castrated in early spring, 1909, when a little less than a year old. The right testis of No. $190^{7}$ was removed at this same time, but the left was not removed till August 8. The left testis of No. I $0^{7}$ (hatched spring 1908) was removed August 8 , but owing to excessive bleeding, the right was well ligatured and allowed to remain. These two males were in summer plumage when operated on. No. $24 \%, 12$ weeks old, was castrated August I3. No. I $0^{7}$, No. $24 \%$ and No. 4 웅 are still alive.

Results.-Males: No. 470 did not take on the summer plumage in 1909. He was unfortunately killed by dogs in spring of 1910. No. I molted in August, I9I0, but did not take on the summer

${ }^{1}$ Not including several others which died in the early part of the work. 
plumage except for a few feathers of head, throat and breast. No. 19 with one testis and this injured assumed the summer plumage in 1909). He did not long survive the second operation.

Evidently the presence of the active (?) testis is necessary for the male to assume the summer plumage. The presence of the ligatured testis of No. I indicates that ligaturing is as effective as removal. I do not know the present condition of the testis of this male. There was no assumption of female characters by any of these males.

Females: No. $t$ and No. 24 were the only females that lived more than a few day's after the operation. October 20, I909,

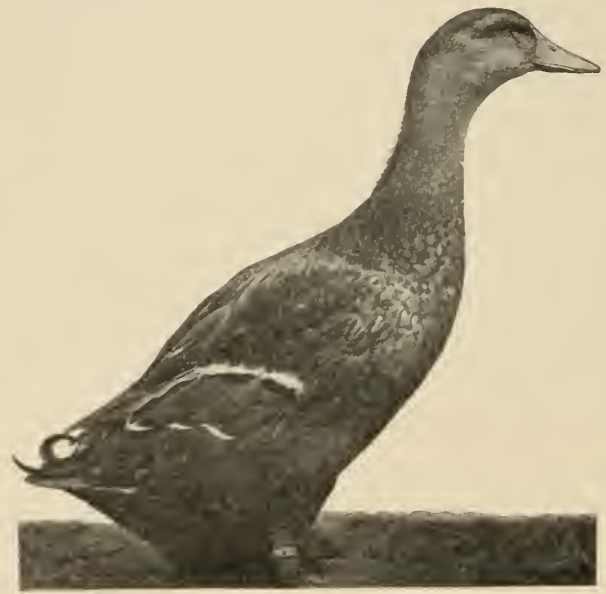

Fig. 9. Female 4, castrated.

they showed no marked modifications, though a small sample of No. 24's breast feathers, saved at that time, are now found to be quite like those of the male in summer plumage. Those of No. 4 were of the usual female type. Through the winter and spring, these two, with several other females were confined in a rather dark pen. During this time, only cursory observations were made, for it was believed that the experiments had failed. July 4, 1910, this flock, for the first time in several months, was 
given their liberty out of doors. This procedure at once revealed that two individuals carried sex feathers. As no males were with the flock, they were immediately examined carefully. Their band numbers, of course, provided the necessary identification. No. 4 (Fig. 9) in addition to the sex feathers, had breast feathers similar to those of the male's breast in summer plumage. In a few feathers, gray vermiculations were present. Such other

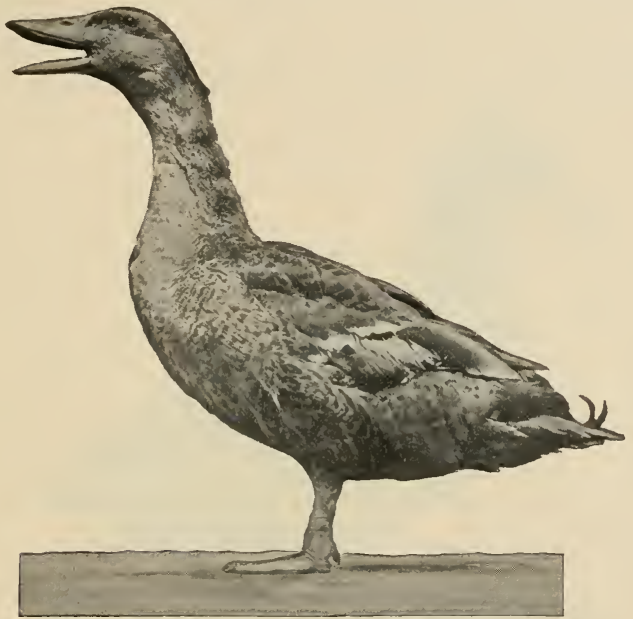

FIG. Io. Female 24, castrated. Photographed August.

modification as had taken place (e. g., very little buff in dorsal regions) was not beyond the range of variation in normal females. No. 24, Fig. I0, was rather more strongly modified. She had a very narrow white neck ring. The feathers of the breast were distinctly of the male type (Fig. $4, I, J$ ). Those of the dorsal side of the lower neck region were of a type occasionally occurring in the same region in males. In other parts of the body there was a distinct tendency for the buff bands to become transverse. Compare Fig. $6, G, H$. Feathers, more or less vermiculated, were quite common. A few found in the anal region, were indistinguishable from similar male feathers. Compare Fig. 8, $G$ with $J$. 
The next molt of these birds, hegun in September, is now (November) well advanced. On the whole No. 4 has made little advance toward the male type. There is much more buff in the dorsal regions than previously, but as stated above, the diminution of buff as noted in the summer was not beyond the range of variation in normal females. On the other hand, a distinct neck ring is now present where earlier there was only a trace.

No. 24 (Fig. II), on the contrary, has made a distinct advance toward the male type. Compare Fig. Io with Fig. II. A comparison of Fig. 11 with Fig. 3 shows how closely she resem-

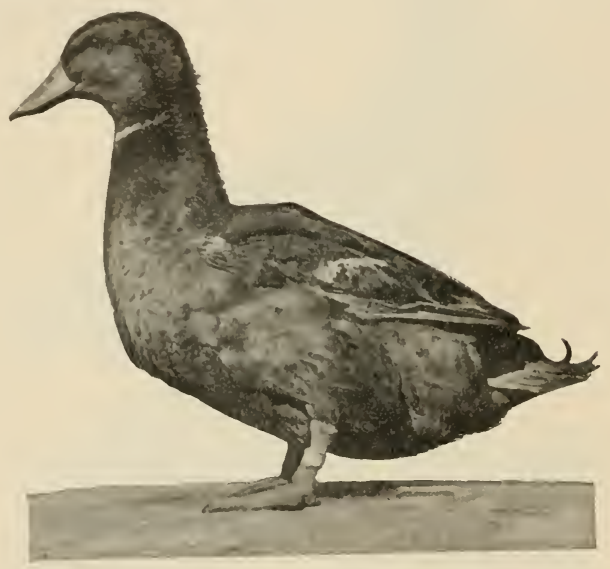

FIG. Ix. Female 24, castrated. Photographed November.

bles the male in summer plumage, even though there are still many unshed feathers of last summer's coat.

Description.- - Head mostly that of female type but in addition numerous brilliant green feathers just like those of the male have developed, though at present they are confined to the dorsal surface. Neck ring better developed than previously. The feathers of the dorsal surface are very similar to those of the male (Fig. 6, I, Fig. $7, G, I I)$, though on the back towards the neck, feathers like those shown in Fig. $6, G, J$, are common. The new feathers of the keel are shown in Fig. $5, H, I$. The upper one 
is the more common. Its transverse buff bands recall those of the young male. The new feathers around the vent and sides of body posterior to wings (Fig. $8, G, F$ ) are largely of the male breeding plumage type, though those of the sides are somewhat darker, more like the feathers of the same place in summer plumage. The new laterals are of the male summer type. Conditions in the breast region are rather complex. The upper part as a whole, is a deep claret, gradually becoming lighter ventrally and shading into the keel region. There is no sharp boundary as in the male. A feather from the upper (anterior) region is shown in Fig. 4, L. Further down on the breast, types like that shown in Fig. $4, K$, are very common. The types shown in Fig. $4, B$, Fig. 5, $I$, and Fig. 6, $G$, also occur, the last being especially frequent at the sides.

This female evidently is still undergoing modifications and in due course of time may assume the complete plumage of the male. At present she has the following distinctively male characters. Brilliantly green feathers on head; white neck ring; much claret in breast and some feathers indistinguishable from the male's; numerous vermiculated feathers, often identical with those of the male; rump feathers like that of male; and sex feathers. I have not seen feathers like those shown in Fig. 5, $H, I$; Fig. $6, G$, in either normal sex, though feathers suggesting the last have been seen in the male. The few feathers of purely female type remaining are in the head and upper surface of wing. The color of the bill has not changed. The voice, too; is still the female's, though it has a tendency to break.

All that can be said in regard to sexual behavior is that the castrated females seem quieter than the others. Fuller observations will be made when the breeding instincts of both sexes become more active.

While the difference in plumage between these females may be due to the difference in age when castrated, no discussion of this point will be attempted in the present paper.

Discussion.-The results of these experiments show that removal of the testes does not bring about the assumption of the female characters, but at most results in the loss of a male character. The loss of the power of taking on the summer plumage 
is similar to the loss of power by the castrated stag of renewing the antlers each year. Whether castration of the drake, very early in life, will prevent the assumption of the breeding plumage will be determined later.

Removal of the ovary, however, has an entirely different result. The female after a time may gradually lose her normal characters and assume those of the male. The results entirely confirm previous observations along this line. Darwin records a duck which in old age assumed the perfect winter and summer plumage of the drake. Korscheldt also records a similar case.

Similar changes occur in fowls. The capon is well known. He is larger, heavier, "softer" and more sluggish than the normal male. He is said never to crow. Comb and wattles are poorly developed, but the other secondary sexual characters may be fully developed. Shattock and Seligmann, however, appear to have found that this development takes place only when some testicular material remains behind. But the age of the bird when castrated may have an important bearing on this point. Stags when castrated very young develop only a very small spike, though the castrated adult retains large antlers. Likewise, a bull, castrated when mature (called a "stag"), differs little from the normal adult. The bull, castrated as a calf, on maturing differs in several respects from the normal adult. Castration of the cockerel, then, has two results. First, it may result in the failure of some of the secondary sexual characters to develop; second, it brings about certain other modifications not associated with secondary sexual characters. There is an interesting peculiarity of the capon. He is said to be capable of being trained to brood and care for chicks. It is doubtful, though, if this is the acquirement of a female sexual character, for he apparently does not become broody, but merely is easily trained to care for the chicks. Poulards are less well known, but may be expected to develop male characters. Waterton records such a case, not resulting, however, from surgical castration (cited by Darwin).

In mammals the general results seem to be quite similar. The castrated female is commonly supposed to assume male characters. The male on the other hand merely fails to develop his secondary sexual characters, which remain in a more or less 
youthful condition. In addition castration may have specific results, not associated with secondary sexual characters. Tandler and Grosz have recently made an extensive study of eunuchs which may be briefly and incompletely summarized as follows: The individual tends to retain youthful characters. Thus the larynx is like that of a boy; the voice high pitched and likely to break similarly to that of a boy at puberty; beard, body, axial and pubic hairs sparse or wanting. The epiphyses remain open for a long time, consequently the eunuch is usually very long limbed. Fat tends to develop in certain parts of the body. The skin is usually soft, poor in pigment, and of a peculiar yellowish color. Facial wrinkles of a peculiar type are also found. The effects of castration of male deer and cattle have been noted. Less is known of the doe, but horns sometimes develop, apparently as the result of abnormal ovaries (Rorig). Similarly in the Hardwick breed of sheep, which are horned in the male only, the horns fail to develop after castration (Shattock and Seligmann). In reindeer, however, where both sexes are horned, castration does not affect the development or renewal of the horns. Other vertebrates have been little studied. Nussbaum, however, finds that the nuptial organs of the male frog do not develop on castration.

Experimental castration in insects has been studied by Oudemans, Kellogg, Regen, Meisenheimer and Kopec. The last two have also transplanted the gonads from one sex to the other. They agree that no modifications of the secondary sexual characters occur. Wheeler, who has recently made an extensive review of the subject, including its physiological side, reaches the same conclusion.

In some other arthropods, however, very different results have been obtained. Giard, Smith and Potts have studied parasitic castration in various crustacea. Their results may be summarized thus: The secondary sexual characters of the female remain unaltered, but the male becomes more or less modified in the direction of the female. In extreme cases, after recovery, ova have been found in the testes, the individual having become hermaphroditic.

This brief review shows that castration varies in its influence 
in different groups. In a given species, castration remodels the secondary sexual characters of only one sex. The case of the stylopized Andrenidxe recorded by Perez, in which reciprocal modifications took place, seems in the light of present knowledge to be somewhat doubtful (Wheeler). At present, then, the effects of castration, so far as it affects the secondary sexual characters, agree with breeding experiments in indicating that one sex only is heterozygous for sex.

The view that the male in birds owes his secondary sexual characters to the addition of something to the female type, is not supported by these experiments on ducks, for it is quite clear that the female owes her color to the ovaries or something associated with them, which previous to castration, suppressed the male characters and which insured the development of her own type of plumage. The female's plumage is obviously a protective adaptation. From an evolutionary standpoint, it is quite as conceivable, that selection should operate to pick out the inconspicuously colored females, as that the greater vitality of the male, or a selection of the more brilliantly colored males by the females, should bring about an addition to the female's type of plumage.

For the present, I think it makes little difference whether we assume that the ovaries themselves or a modifier always transmitted with the ovaries, prevents the development of the male characters. The evidence of the possible presence of a modifier, however, renders possible a somewhat different suggestion regarding the mode of sex-limited inheritance than has previously been expressed. ${ }^{1}$ It involves also a number of possibilities regarding the inheritance of sexual dimorphism of plumage.

The Brown Leghorns are highly sexually dimorphic in plumage. In cross breeding it is found that the female transmits this color to her male offspring only, though the male transmits it to all his offspring. Barring, likewise dimorphic though in less degree, is transmitted is the same way. But that this is a universal rule for poultry with sexually dimorphic plumage appears to be somewhat doubtful. The penciling of the Dark

${ }^{1}$ Sex-limited inheritance appears to occur in ducks. A paper on this subject in preparation. 
Brahma female seems to be transmitted to the female offspring only, without regard to whether the Brahma is mother or father (Davenport). But there are some possible complications resulting from the particular matings made, which make this point uncertain. Thus far, however, the study of sex limited inheritance including the invisible factor " $D$ " described by Bateson for the Brown Leghorn and the castration experiments on ducks all point in the same direction.

Some of the possibilities in the mode of inheritance of sexually dimorphic plumage are as follows:

I. In the female we may assume that the plumage occurs as a typical Mendelian heterozygote of male color and female color, ${ }^{1}$ the former being considered recessive. The male, then, must be a homozygous recessive. But such assumptions do not agree with the results of breeding experiments as mentioned above for they show that in the female, a color factor occurs in only half her gametes.

2. Among the various other ways of representing the mode of inheritance of sexually dimorphic plumage, the following seems the nearest approach to our present knowledge. Assume that the male is homozygous for sex, the female heterozygous; that the male color (or color factor) $m c$ also is homozygous in the male, but in the female heterozygous, the other element of the pair being an invisible modifier, $M$, which always couples with femaleness; or, assume that the male color always couples with maleness. Then the male is $m c m c$, gametes all $m c$; the female is $\sigma^{7} \sigma^{3}$ or

$m c M$, gametes $m c, M$. The breeding experiments mentioned $0^{7}$ 우

above afford the reasons for assuming that the male is homozygous for sex, and the female heterozygous, and for the assumed couplings. The castration experiments give the reason for assuming a male color and a modifier. The expression, male color, however, is used in a purely descriptive sense. I do not wish to be understood as giving it any special significance.

3. By the additional assumption of selective fertilization, the male can be shown to be heterozygous instead of the female,

${ }^{1} E$. g., male Brown Leghorn color and female Brown Leghorn color as such. 
thus: Male $m c m c$, gametes $m c, m c$; female $m c M$, gametes $\sigma^{7} \quad$ क $(x) \quad \sigma^{7} \quad \%(x) \quad \%(x) \%(x)$

$m c, M$. The only matings to be regarded as possible are $m c$ by 우 $(x)$ ㅇ $(x)$

$M$ and $m c$ by $m c$.

o $(x) \quad$ क $(x) \quad \sigma^{7}$

The $x$ in parenthesis is given as an alternative mode of representing sex by the $x$-element. This mode of representation would bring the experimental results into line with Guyer's discovery of an accessory in fowls.

The modifier assumed can hardly be specific for every type of dimorphism, else in cross breeding the later generations of females should show various modifications of the original female type. Of this there is no evidence. The modifier may, of course, be femaleness itself, in which case a somewhat different mode of representation should be employed.

It is obvious that Guyer's discovery of an accessory in fowls is contradictory to the results of experimental study which indicate the correctness of the Bateson-Spillman theory of sex in fowls, unless selective fertilization is assumed. Even if this be done, the male color obviously cannot be transmitted by the idiochromosomes. There is, of course, the possibility that the $x$-element is not a sex determiner at all, but merely a further indication of sex dimorphism. On the other hand the discovery of cocks which in cross breeding transmit some character to their female offspring only, would disprove the Bateson-Spillman theory. Hagedoorn seems to have found such a case, but he does not seem to have noticed its implications. A reëxamination is desirable.

Before proceeding further, a brief account will be given of some modifications of sex.

Braem, while studying regeneration, removed the last 22 segments of 35 in a female Ophryothrocha. Later he found that the ova in the anterior sections were degenerating and spermatozoa developing. Hermaphrodites often occur in Ophryotrocha, but in these the male germ cells always develop first, exactly the reverse of the present case.

During the past summer, my attention was attracted to certain changes in sex in maize, which is monœcious. The maize plant consists of a single stalk, at the apex of which is the tassel bearing. 
the anthers. The female reproductive organs, forming the "ears," arise from axils of the leaves about midway of the stalk. In some varieties secondary stalks called suckers may arise near the base of the plant. They are usually devoid of ears, but almost always produce a tassel.

Sometimes, however, kernels of corn develop on the tassels. These appear to be always associated with a smut fungus. These kernels were often very numerous on the tassels of suckers, occasionally a fair resemblance to an ear being formed.

Stamens are less easily found on the ear but they may occur at its apex. This may mean that the germ cells, which normally would produce ova, develop into male cells, but since the ear is morphologically the equivalent of a branch it may mean only an abortive attempt at the development of the branch. Since these observations were made, Professor Morgan has kindly called my attention to the splendid work of Bleringhem on maize. My results as far as they go entirely confirm Bleringhem, though the alteration in sex patency appears to be brought about by a different cause.

The case of Lychnis dioica, studied by Giard, is interesting. "The young is hermaphrodite, but in certain individuals the ovaries abort, in others the stamens remain rudimentary." Other instances in plants are cited by Bleringhem.

These instances are sufficient to show that what seems to be only one sex may really be both sexes with one of them suppressed. Compare also Smith's studies on Inachus.

At the present time, the evidence available in regard to the nature of sex and its determination is very contradictory. The observations of Smith on parasitic castration in Crustacea, the experiments of Morgan with Drosophila, and the studies of Wilson and others indicate that the female is pure for femaleness, but that the male is a sex hybrid of maleness (dominant) and femaleness. Diametrically opposite evidence is afforded by the experiments of Doncaster on Abraxis, followed by experiments on other forms by several other investigators, which favor Bateson's theory of a sex heterozygous female (femaleness dominant) and a sex homozygous male. There are still other experiments which favor neither view.

'The quotation is taken from Wheeler's paper. 
In spite of these contradictions, sex is such a well nigh universal attribute of living beings, that there would seem to be some equally common differences between the sexes. It hardly seems reasonable to suppose that femaleness, for example, is one thing in one group and something else in another. But whatever the common difference between maleness and femaleness as such, it by no means follows that this difference of itself determines the sex of an individual. Instead, other factors may be responsible.

The observations on Ophryotrocha, Inachus, Lychnis and maize afford evidence of the presence of factors which control the patency of sex, so that what is really hermaphrodite may appear to be unisexual. The case of Siline inflata, cited by Correns from Schultze, also points toward the presence of factors which modify hermaphrodites. There are five different types, males, andromonœcious (males and hermaphrodites on the same plant), hermaphrodites, females and gynomonœcious. Moreover, according to Correns and Shull, crossing hermaphrodites and unisexual forms results in dominance of the unisexual forms.

If we assume that hermaphroditism, which is very much more common in plants and the lower animals than in the higher animals, is the primitive condition, we have a basis from which may be derived the present diverse modes of sex determination. During the course of evolution, various changes have occurred in the gametic constitution of some individuals or modifying factors may have developed, which brings about our present diverse modes for the determination of sex in the individual. That the determination of sex, even from a Mendelian standpoint, is not brought about by the simple interaction of maleness and femaleness, is shown, I think, by the deviations from equality in the sex ratios. In man, for instance, there is a slight but constant excess of males at birth, whereas on the assumption that one sex is heterozygous, the other homozygous, either equality should be expected, or that sometimes the number of female births should exceed the male births.

Though our present evidence undoubtedly favors the view that the female fowl is a sex heterozygote, it does not necessarily follow that she is therefore a potential hermaphrodite. The hermaphrodite, it is true, may be considered as a sex heterozygote, 
but with both sexes patent. On the other hand maleness and femaleness may each exist in the same individual in a homozygous condition, which may be expressed in Mendelian form, thus: $0^{7} 0^{\pi}$
$o q$ the primitive hermaphrodite, other formulæ serving for existing forms.

\section{SUMmary.}

I. The castrated drake retains his secondary sexual characters, except the ability to assume the summer plumage.

2. The castrated duck (female) assumes, more or less completely, the secondary sexual characters of the drake. The change, however, is very gradual.

3. It is suggested that the female owes her color to the presence of some modifying element, which prevents the development of the male color. It is also suggested that the modifier may sometimes be responsible for sex limited inheritance.

4. Cases in which the patency of sex has changed are pointed out. This suggests that a common basis for the present contradictory evidences regarding the determination of sex may be found in the hermaphroditic condition.

\section{Bateson.}

\section{LITERATURE.}

'og Mendel's Principles of Heredity. Cambridge, I9og.

Bleringhem.

'07 Action des traumatismes sur la variation et l'heredite. Lille, I907.

Braem.

'o8 Über die Aenderung des Geschlects bei Ophryotrocha. Anat. Anz., Bd. 33. 1908.

Correns.

'o7 Bestimmung und Vererbung des Geschlechtes. Leipzig, I907.

Coues.

'96 Key to North American Birds, I 896.

Darwin.

Animals and Plants under Domestication, Vol. II.

Davenport.

'o6 Inheritance in Poultry. Carnegie Inst. Washington, I906.

Doncaster and Raynor.

'o6 Breeding Experiments with I.epidoptera. Proc. Roy. Soc., I9o6.

Goodale.

'xo Breeding Experiments in Poultry. Proc. Soc. Exp. Biol. Med., Vol. 7, I9ro. Guyer.

'og Spermatogenesis of the Domestic ('hicken. Anat. Anz., Bd. 34, I909. 


\section{Hagedoorn.}

og Mendelian Inheritance of Sex. Arch. Ent. Org., Bd. 28, I909.

Kellogg.

'04 Influence of the Primary Reproductive Organs on the Secondary Sexua ('haracters, J. Exp. Zoöl., Vol. 1, 1904.

Kopec.

'10 Ueber Morphologische und Histologische Folgen der Kastration und Transplantation bei Schmetterlingen. Bull. Acad. Sc. Cracovie, I910.

Meisenheimer.

'og Experimentelle Studien zur Soma und Geschlechts Differenzierung. Jena, 1909 .

Morgan.

'10 Sex Limited Inheritance in Drosophila. Science, Vol. 32, I910.

Nussbaum.

'05 Innere Sekretion und Nerveneinfluss. Erg. Anat. Ent., Bd. XV., 1905.

Oudemans.

'99 Falter aus castrierten Raupen. Zool. Jahrb. Abt. Syst., Bd. XII., I899.

Potts.

'og Some Phenomena Associated with Parasitism. Parasitology, Vol. II., 1909.

Regen.

'ro Kastration und ihre Folgeerscheinungen bei Gryllus campestris. Zool. Anz., Bd. 34, 1909; Bd. 35, 1910.

Rorig.

'99 Welche Beziehungen bestehen zwischen den Reproduktion Organen der Cerviden und der Geweihbildung derselben. Arch. Ent. Org., Bd. 8, 1899.

Shattock and Seligman.

'03 Observations on the Acquirement of Secondary Sexual Characters. Proc. Roy. Soc. London, Vol. 73, I903.

Shull.

'ro Inheritance of Sex in Lychins. Bot. Gaz., Vol. 49, 1910.

Smith.

'o6 Rhizocephala. F. F. Golf. Neapel., Mon. 29, 1906.

Tandler and Grosz.

'10 Ueber den Einfluss der Kastration auf den Organismus. Arch. Ent. Org., Bd. 30,1910 .

Wheeler.

'ro The effects of Parasitic and Other Kinds of Castration in Insects. J. Exp. Zoöl., Vol. 8, 1910.

\section{Wilson.}

'og Studies on Chromosomes, IV. J. Exp. Zoöl., Vol. 4, 1909. 

H. D. GOOI)ALE.

\section{Plate I.}

FIG. $4 \cdot^{1}$ Breast feathers from: $A$, male No. 29 in breeding plumage; $B$, occasional variant from $A$. $C$, same male; $D$, a different male, both in summer plumage. $E-H$, normal females; $E$, from female No. 26 in November; $F$, from same female in August; $G$ and $H$, from two other females. $I-L$, from female No. 24, castrated; $I$ and $J$, August; $K$ and $L$, November; $J$ and $L$ were from the upper part of the breast; $I$ and $K$ from the lower part.

${ }^{1}$ The buff or reddish bands in the originals of Fig. $4, D, F, K$; Fig. $6, C, F, I$, $J$; Fig. $7, D, E, F$ failed of reproduction in the plates. 

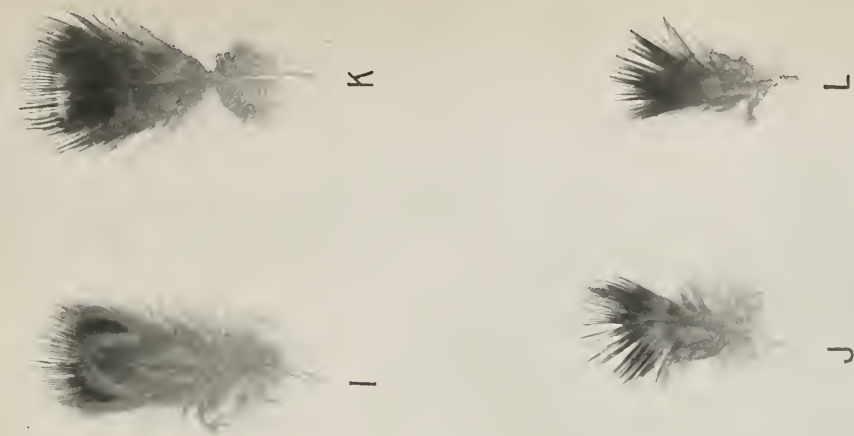

$\supset$

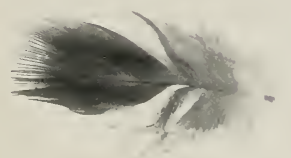

ᄂ.

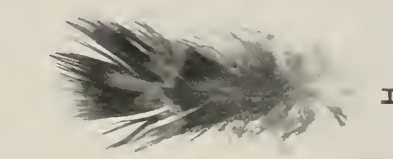

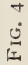

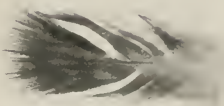

$\circlearrowleft$

w
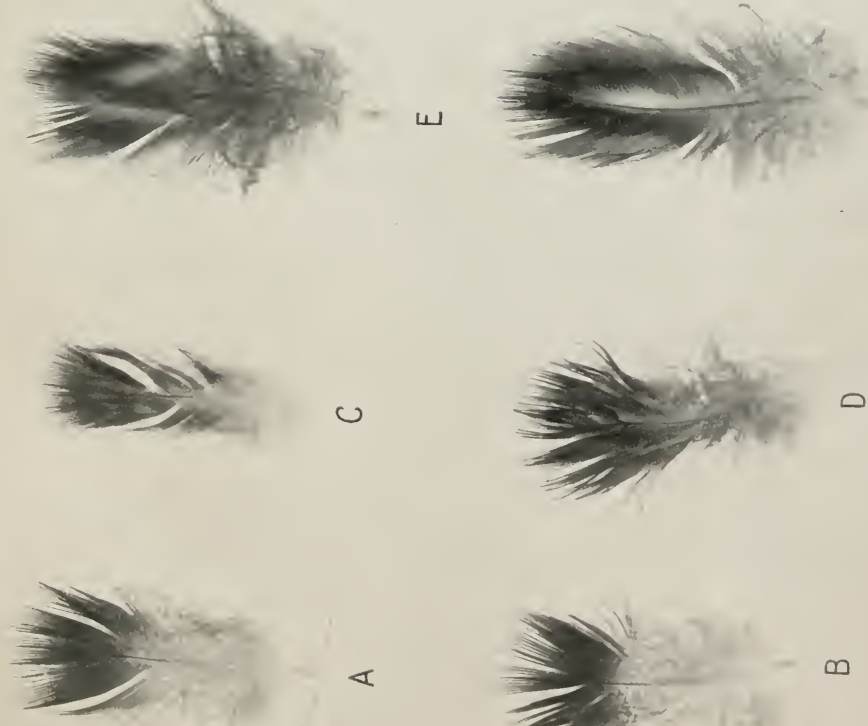

$\varangle$
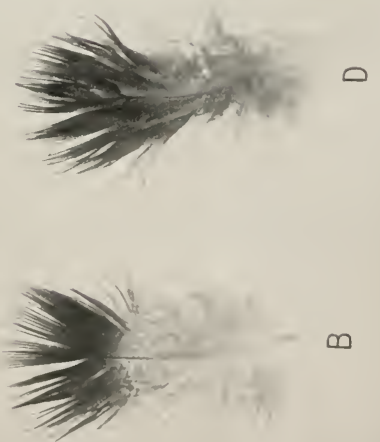

11. 1). GOOI)ALE.

Plate II.

FIG. 5. Feathers from near the front end of keel. $A, B, 29 \sigma^{7}$, breeding plumage, $A$ being the more common type. $C, D, 29 \sigma^{7}$, summer plumage; $C$ is usual type. $E, F$, normal females; $E, 26$ ㅇ $F, 4 \mathrm{I}$ ㅇ․ $G-I, 24$ ㅇ, castrated; $G$, August; this feather from middle keel region; $H, I$, November, $H$ being the common type. 


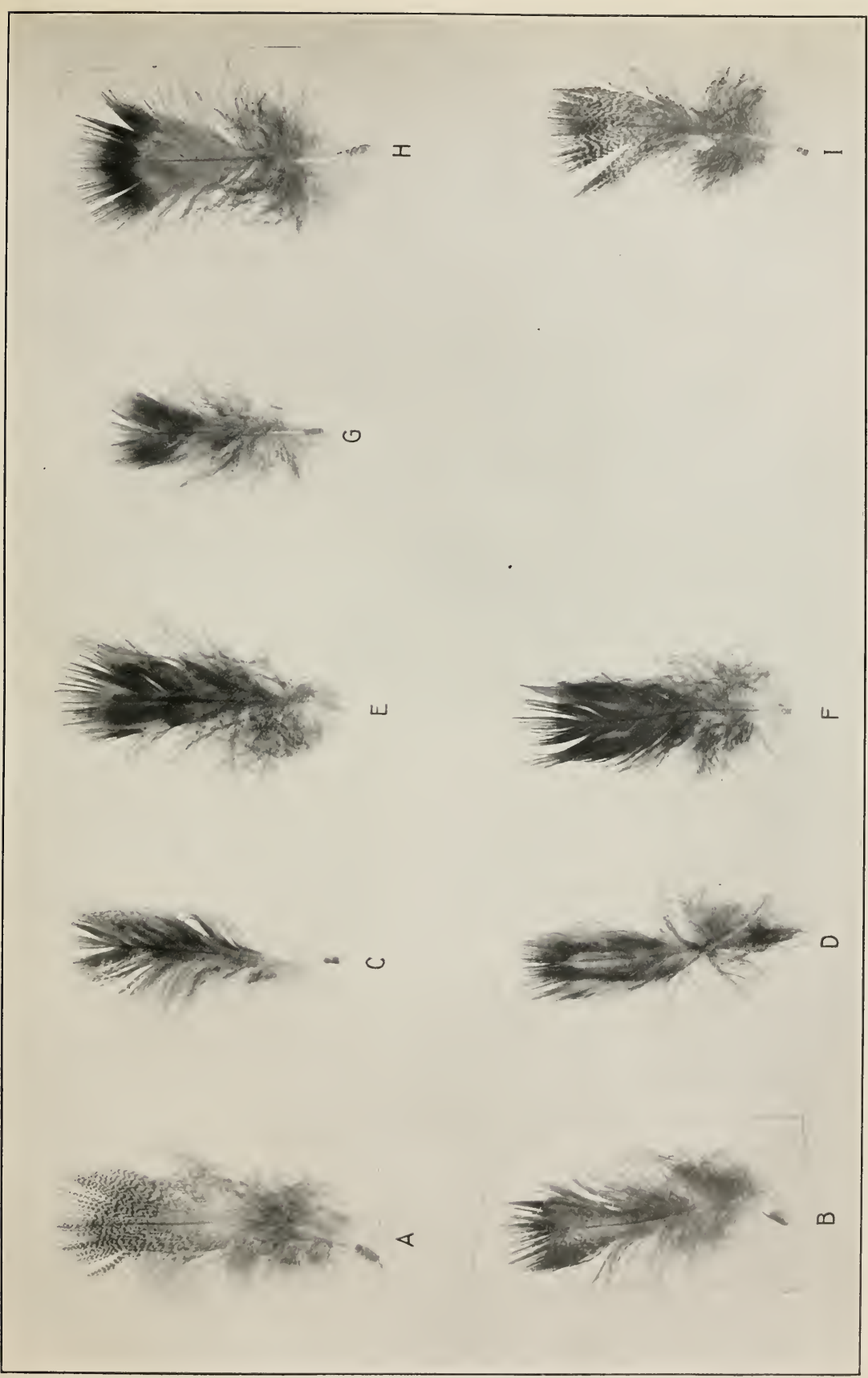




H. I). GOOI)AI.F.

Plate III.

FIG. 6. Feathers from dorsal surface near juncture of neck with body. $A, B$, $29 \sigma^{7}$, breeding plumage; $A$, common type. $C, 29 \sigma^{7}$, summer plumage. $D-F$, normal females; $D, 26$ 오, November; $F, 26$ 우, August; $E, 4 \mathrm{x}$ ㅇ. $G-J, 24$ 우. castrated; $G, H$, August; $I, J$, November; $I$ is more common than $J$. 

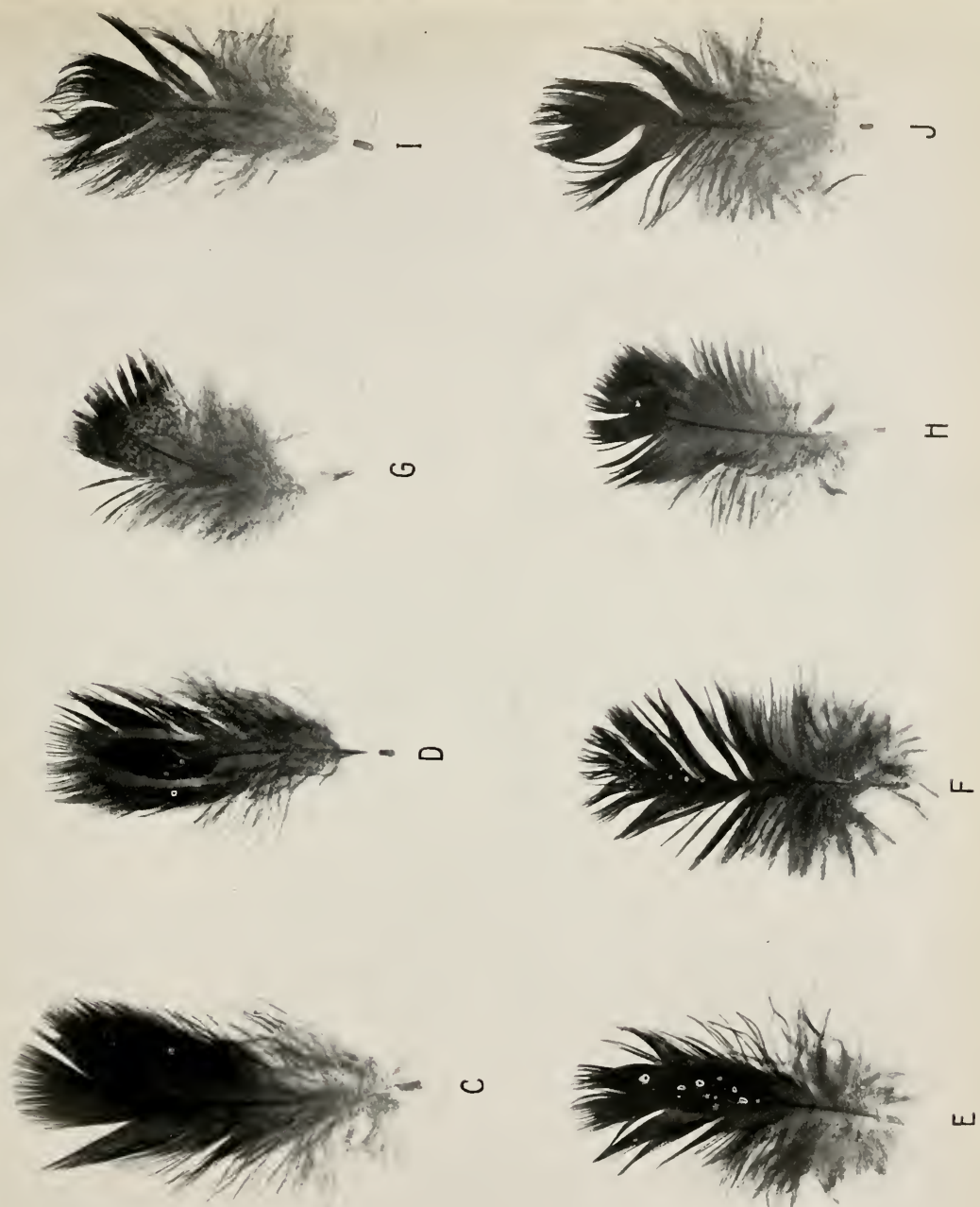

u

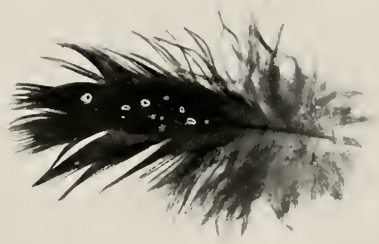

$w$
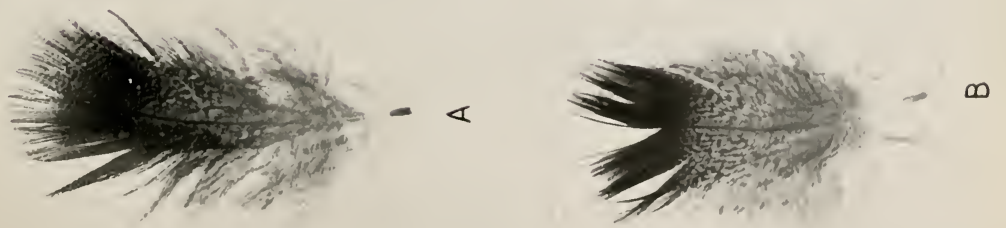


Plate IV.

FIG. 7. Feathers from rump. $A, 29 \sigma^{7}$, breeding plumage; $B$, summer plumage. $C-E$, normal females; $C, 26$ \% , November; $D, 26$. August; $E, 4 \mathrm{I}$ \% . $F-H, 24$ \% , castrated; $F$, August; $G, H$, November. 


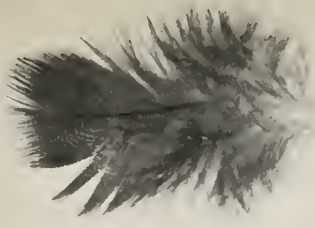

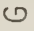
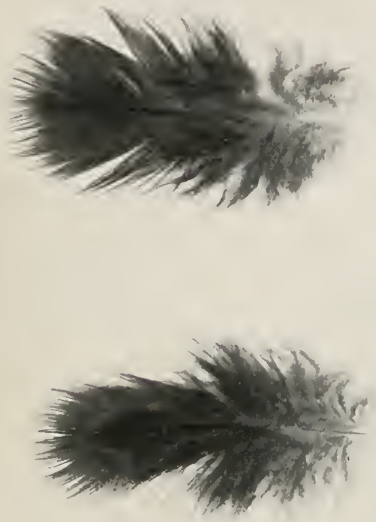

$\omega$

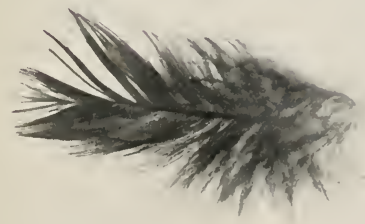

$\infty$
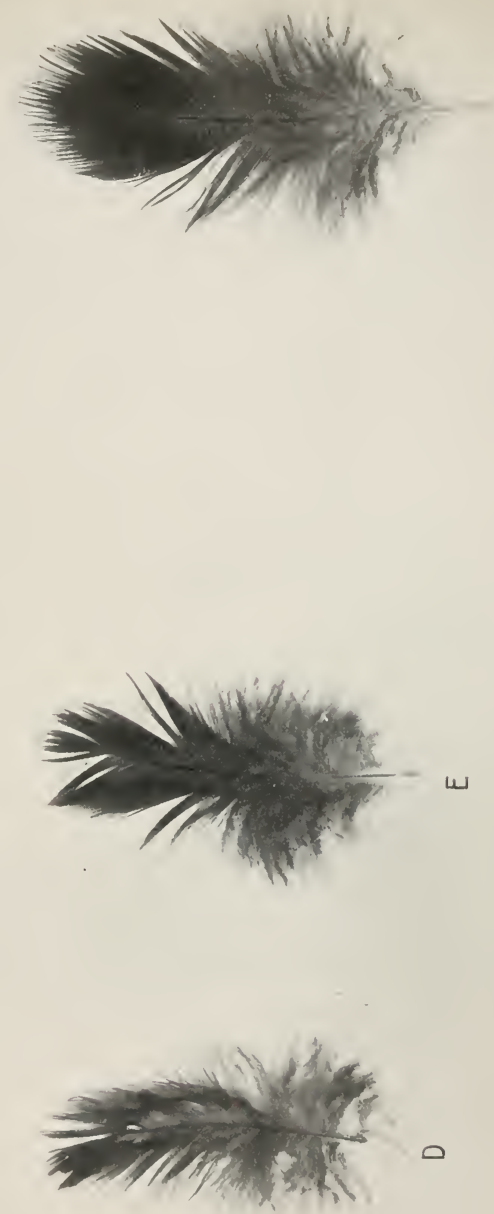

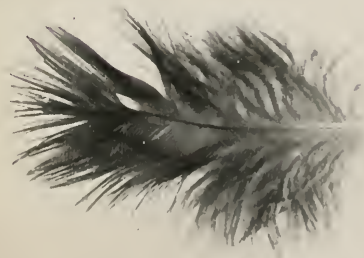

: 




\section{Plate V.}

FIG. 8. $A-C$, at juncture of wing and body: $A, 290^{7} ; B, 24$, castrated; $C, 26$ \% , normal. $D$ and $E$, breast feathers: $D$, young male; $E$, young female. $G, I$, posterior to vent: $G, 24$ ? castrated; $I, 29 \sigma^{7}$, breeding plumage. $F, H, J$, sides of body dorsal to vent: $F, 24 \%$ castrated; $H, 29 \sigma^{7}$, summer plumage; $J$, $29 \sigma^{7}$, breeding plumage. For normal female feathers compare Fig. 5, E, F. 

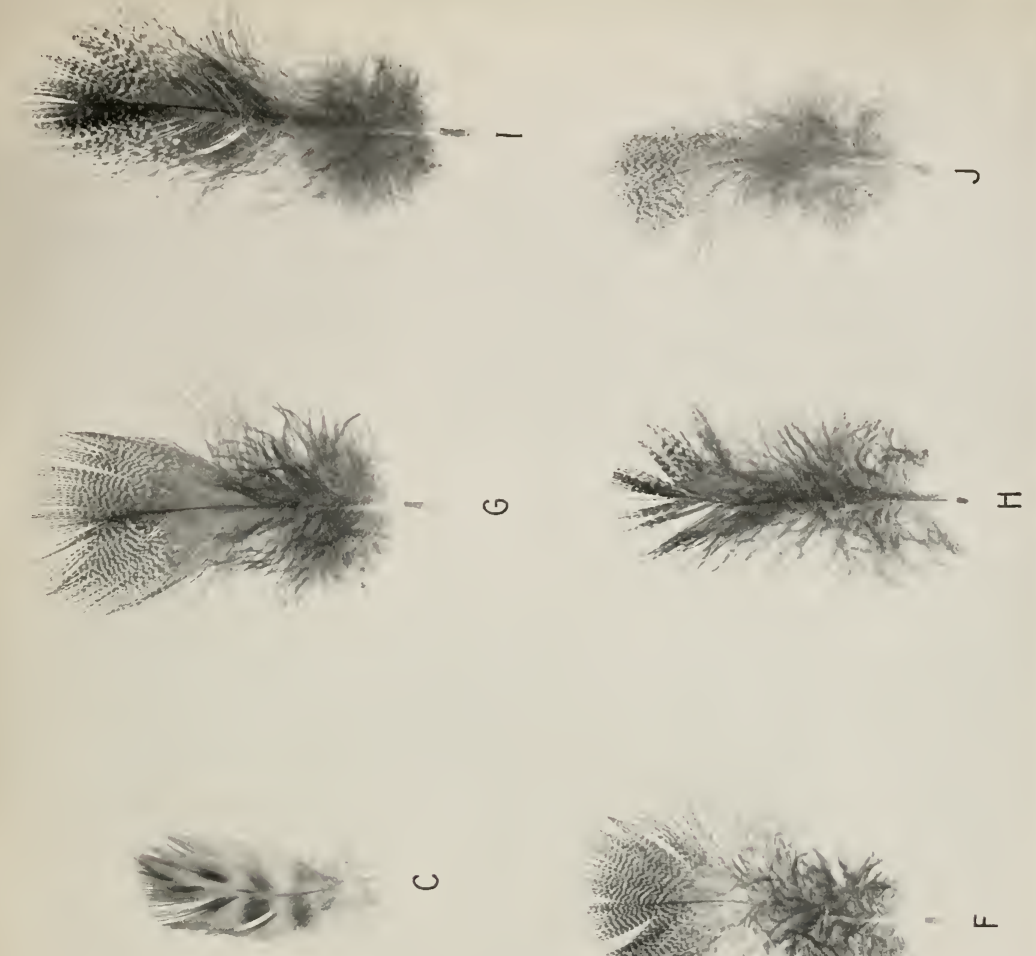

$\cup$
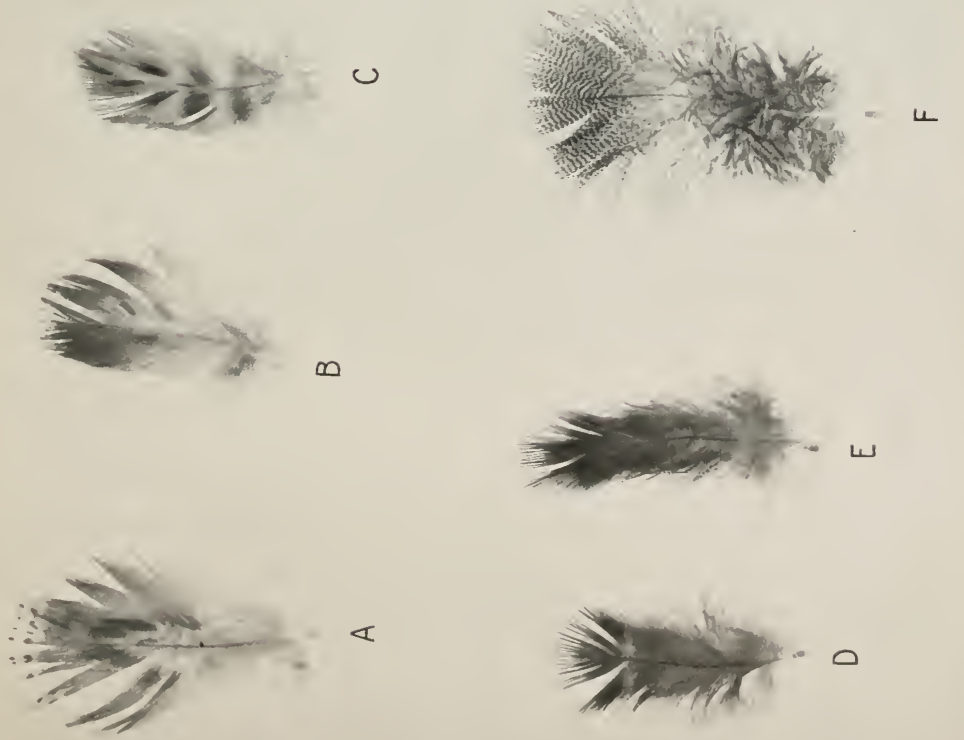

$\stackrel{\infty}{\dot{I}}$ 








THIS BOOK IS DUE ON THE LAST DATE STAMPED BELOW

AN INITIAL FINE OF 25 CENTS WILL BE ASSESSED FOR FAILURE TO RETURN THIS BOOK ON THE DATE DUE. THE PENALTY WILL INCREASE TO 50 CENTS ON THE FOURTH DAY AND TO \$1.00 ON THE SEVENTH DAY OVERDUE.

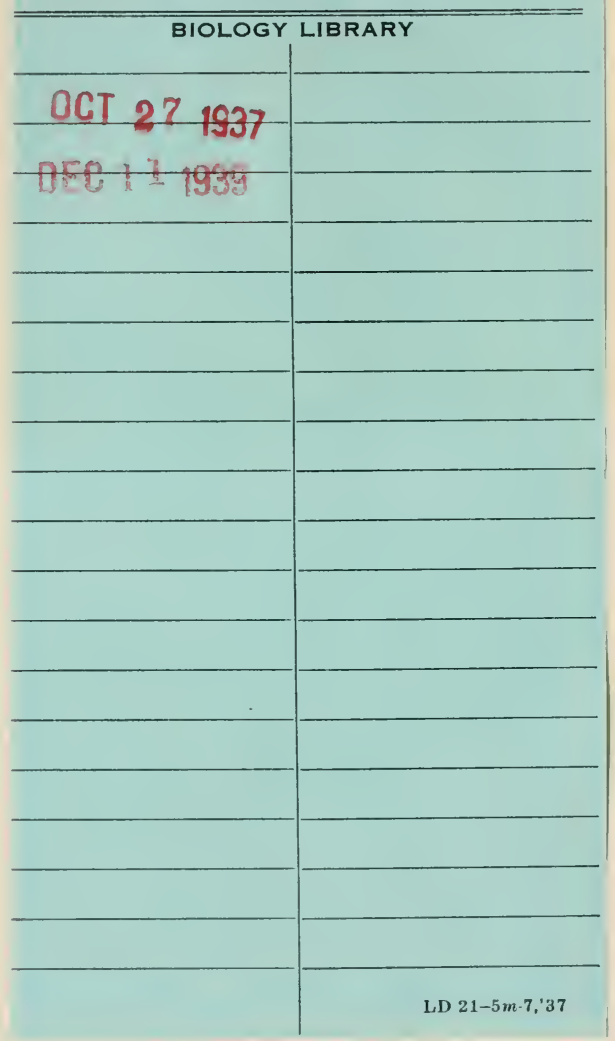


SEa 35

G6

320868

EIOLOGY

LERARY

$\frac{6}{2 !}$

$G$

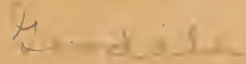

4

$\frac{2}{3}$

UNIVERSITY OF CALIFORNIA LIBRARY 
